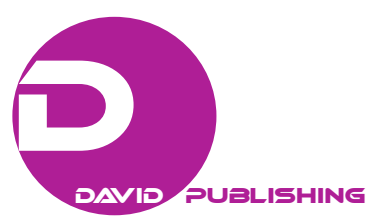

\title{
The Review of Chinese Literary Anthropology Theory's Construction Since 21st Century
}

\author{
GONG Wei-jun \\ Shanghai Jiaotong University, Shanghai, China
}

\author{
SUN Feng-juan \\ Sun Yat-Sen University, Guangzhou, China
}

\begin{abstract}
Important changes have taken place in the study of Chinese literary anthropology since 21 st century. Chinese literary anthropologists make every effort to explore and construct one theoretical system which is suitable for China's local culture consciousness. Its development context is clear: from literary text to culture text, and from the mythological outlook of literary standard to the mythological outlook driven by faith. We need rely on quadruple-evidence approaches which are integrated with multidisciplinary knowledge to reconstruct Chinese culture of the great tradition and little tradition theory from the new perspective of mythistory, to elaborate $\mathrm{N}$-level coding theory, and to explore the faith in jade myth as the potential driving force of the beginning of civilization. By combing the complete symbolic process from the faith in jade myth to Chinese civilization core values, we wish to seek out the deep cultural genes among Chinese civilization identities ultimately.
\end{abstract}

Keywords: quadruple-evidence approach, mythistory, great tradition and little tradition, faith in jade myth,

N-level coding theory, white jade worship

Literary anthropology in China has been nearly for 30 years of development since the new period. The innovative promotion to the research paradigm and idea of Chinese humanities becomes more and more obvious. As an interdisciplinary research, Chinese literary anthropology created by comparative literature has presented an ascendant trend since 21st century. Many scholars, like Ye Shuxian, Xiao Bing, Xu Xinjian, Fang Keqiang, Peng Zhaorong, Cheng Jincheng and so on, stick to it diligently and firmly, try their best to construct a literary anthropology theory which has Chinese characteristics and then use these theories to explain Chinese literary and cultural phenomenon. However, as an emerging and independent interdisciplinary subject, Chinese literary anthropology is still in the phase of theoretical construction at present, so it inevitably faces the voice of doubt from all directions in the process of exploration. Based on this, the article will make a systematic review of the constructive process of Chinese literary anthropology theory to make its development clear, hoping to predict its development direction in the future.

Ye Shuxian is the outstanding person in the field of literary anthropology, and compared with other scholars in the same period, he insists on his research characteristics, that is, making theoretical exploration and

GONG Wei-jun is a Ph.D. Candidate at School of Humanities, Shanghai Jiaotong University. His research area is Chinese literary anthropology, comparative literature, and cultural theory.

SUN Feng-juan is a Ph.D. Candidate at School of Sociology And Anthropology, Sun Yat-Sen University. Her research area is folklore, cultural anthropology, and economic anthropology. 
critical practice together. He once resonated with Northrop Frye in terms of thoughts in the process of theoretical exploration, so that he thought "the Canadian critic's unique profound knowledge, power of understanding and thinking depth give people a deep impression, to some extent, Hegel is not sufficiently rigorous sometimes"'. He doesn't completely copy Northrop Frye's prototype theory, but makes a reflection on Chinese literary and culture's reality, trying to construct Chinese literary anthropology theory which is suitable for the reality of Chinese literary and in line with Chinese local cultural consciousness. Its basic logic is as follows:

comparative mythology (the end of 20th century) $\rightarrow$ quadruple-evidence approach (2005) $\rightarrow$ mythistory $(2009) \rightarrow$ great tradition and little tradition (2010) $\rightarrow$ faith in jade myth (2010) $\rightarrow$ N-level coding theory (2012) $\rightarrow$ Protestantism revolution of faith in jade myth (white jade worship) (2014)

The theory is still in the initial stage at present, so there are many shortcomings inevitably, and it may also bring about some controversies. But there is no doubt that the evolution of theoretical thinking is interconnected, integrated and tenable. Constructed by literary anthropologists who represented by Ye Shuxian, the Chinese literary anthropology theory highlights multiple interactions among different subjects from interdisciplinary perspective, such as aesthetic anthropology, historical anthropology, archaeology, art anthropology and so on, truly conforming to two trends in 20th century, i.e., "anthropology turning to literary creation and theory, and literature (or humanity) turning to cultural anthropology".

\section{The Paradigm From “Chinese Mythology” Turning to "Mythological China”}

In the middle of the 19th century, Max Müller initiated comparative mythology, contacted the origin of western history and Indian civilization for the first time, and found Indo-European hypothesis. From then on, comparative mythology spread rapidly, even triggered a trend of "myths' hot" in the 1980s of China. As a conceptual tool, myths "exist as a culture gene. It necessarily has basic construction and coding effects on special culture's cosmology, values, behavior and etiquette" ${ }^{\text {"2 }}$ Lévi-Strauss proved the value of the position that wild thinking and scientific thinking are equally important by studying Indian myths of South American. Northrop Frye initiated "mythic literature outlook" which created disciplinary new ideas of literary anthropology. Hayden White prominently argued that history and myths have the same fiction and the nature of metaphor on narrative. It is no exaggeration to say that "the butterfly effect" on comparative mythology in western theoretical field makes literary, history and philosophy under the banner of unification to mythology again. In the other words, mythology is the same origin of undifferentiated literary, history, philosophy, politics, and law, and so on.

Under the background on the above, Ye Shuxian is influenced by western comparative mythological theory. He has completed a number of books, including Mythology-Archetypal Criticism (1987), Structuralism Mythology (1988), Chinese Myths' Philosophy (1992), etc. So he gradually realizes that "different from those litterateurs who lived in the early 20th century, they once acquired myths' concept from western world and found 'Chinese myths' in ancient books. While after the mythology turn, we have got through understanding

\footnotetext{
1 Ye Shuxian, "World Insight" and "Chinese Learning"-My Research on Literary Anthropology, Literature and Art Contending, $1992(5)$.

${ }^{2}$ Ye Shuxian, Chinese History of Myths—-from “Chinese Myths” to "Mythological China”, Journal of Bai Se College, 2009 (1).
} 
myths' concept, in order to lead our radical comprehensive understanding for Chinese culture"3. Therefore, under the thinking of global culture roots movement in the new century, he updates and reviews the past concept of "myths", proposes to "get out of the mythological outlook of literature-centered concept", and complies with the creational trend of "new mythicism". All of that prominently are performed in his series of books, such as Mythological Image (2007), The Totem Bear (2007), and Confucian Myths (2011), and so on.

From finding and defining "Chinese myths" to turning to re-recognize and interpret the academic paradigm shift of "mythological China" gradually, Ye Shuxian makes his effort to do the preceding mythology exploration. Hoping to change and expand narrow categories in the study of Chinese mythology, he lets myths as resources and cultural prototype codes, at the same time, continuously pays attention to the mythological expression and faith of life in the ideological archaeology about mythological image.

By this token, "Chinese myths" concept corresponds with literary texts, which has driven modern humanists to find narrative works about ancient Greek and Roman mythology in Mountains-Seas Book (山海 經). However, limited by writing history of Chinese characters, it can only be traced back to the oracle age of more than 3,000 years before. While "mythological China" concept corresponds with cultural texts, which breaks through the limit of pure texts, leads us through various disciplines' conformable cognitive perspective, including literary, history and philosophy, and lets us re-interpretate mythological thinking about image narration discovered in archaeological findings and folk narration existing in living cultural heritage. So from "Chinese myths" to "mythological China", the paradigm turning is a great progress that "chinization" of comparative mythological theory takes "archetypal criticism" as theoretical orientation.

\section{Quadruple-Evidence Approach: Cultural Texts' Construction and Interpretation}

From "double-evidence approach" advocated by Wang Guowei in the early 20th century to "triple-evidence approach" popularizing in 1990s, intervention of anthropological perspective and methods has begun to change the pattern of traditional Chinese studies. When many people are still exploring the evolution track from "suspecting the past" to "interpreting the past", Ye Shuxian enhances the "triple-evidence approach" to the height of methodology personally and connects traditional Chinese studies with knowledge globalization, trying to use inter-cultural interpretation of triple-evidence approach in the field of Chinese literary anthropology. Meanwhile, he still takes charge of a series of books about "the anthropological decipherment of Chinese culture", such as Cultural Explanation of The Book of Songs (詩經) (1994), Cultural Interpretation of Lao Tzu (老子) (1994), Cultural Analysis of Chuang Tzu (莊子) (1997), etc. As we know, from advocacy to use, the ideological context of "triple-evidence approach", and its modern transformation and revolution in Chinese studies have created many new consequences.

After trying the study and practice of "triple-evidence approach" more than ten years, Ye Shuxian says that he has involved more new materials about Chinese archaeology, observed a number of archaeological sites and cultural relics and also realized these cultural relics and images plays a special narrative and implicated role to prove the concept of religion and myths. So, he constantly rethinks triple-evidence approach to have a further update and advance, until putting forward quadruple-evidence approach in 2005. At the same time, he stresses

\footnotetext{
${ }^{3}$ Ye Shuxian, The Golden Bough and the Jade Leaf-Comparative Mythology from Chinese Perspective, Shanghai: Fudan University Press, 2012, p. 42.
} 
that two theoretical bases of the quadruple evidence are material culture and new history, but this kind of judgment is a reflection of cognitive breakthrough and theoretical consciousness.

Quadruple-evidence approach is a new exploration about Chinese literary anthropology from new theoretical paths to maturity, no longer stays in reflection and critique about the previous pattern of literature and culture, and becomes a new means of sign that scholars can transcend themselves. From "triple" to "quadruple", it is not a simple "pile-up structural model". Ye Shuxian continues to reflect on the theoretical architecture of triple-evidence approach in the above process and changes his research perspective: from single text research to survey of ethnographical fieldnotes, from "writing culture" to living "oral culture".

As to quadruple-evidence approach which is a new methodology of interdisciplinary significance, researchers of literary anthropology devote themselves to the interpretation, supplement and perfection of quadruple-evidence approach from a new angle; they focus on the evidence interrelation between quadruple evidences and every evidence, based on principles of mutual supplement, interpretation and certification, to make quadruple evidences form a special "field" and reconstruct the lost cultural memory in the process of contrasting and reinforcing.

Quadruple-evidence approach draws on the semiologic theory which blends Michel Foucault's discourse theory and Clifford Geertz's cultural semiologic theory. ${ }^{4}$ As for the attitude towards field and texts, oral culture and writing culture, it absorbs Marshall McLuhan's media theory from the view of media change. Taking general rules of human mythological thinking as the core, it embodies Kwang-chih Chang's "structural" thought of social cultural system. But the application of evidence law theory adequately shows the importance of rigorous research attitude advocated by Hu Shi, namely "bold hypothesis, cautious verification".

The reconstruction of knowledge archaeological paradigm and the way of three-dimensional interpretation can confirm the effect of quadruple-evidence approach. At the same time, with the help of many cases about theoretical interpretation, we can endow quadruple-evidence approach with the meaning of humanities' general methodology.

\section{Mythistory: Original Tradition Regression of Historical Memory}

Starting from the perspective of great tradition of literary anthropology, myths always represent a strong gene of human culture as primitive ancestors' self-expression of wisdom, living with the prehistoric religion and ritual performance commonly and playing the most original function of sacred narration. To our delight, as a symbol of human thinking codes, myths are breaking up the wrong view of philosophy that "myths aren't equal to rationality". New historicism insists on making history release successfully from the bottleneck of "historical science", recovering the same imaginary and metaphorical nature between historical narration and mythological narration, and returning to the authenticity of history at last. It is also no wonder that Michel de Certeau signs: "History is probably our myths!"

The tension between myths and history doesn't happen in two different things but the same thing. Unluckily, modern paradigm still rules artificially the standard of division between myths and history, so it makes people's value judgment inevitably fall into an unanswered circle which framed by themselves: myths

\footnotetext{
${ }^{4}$ Dai Yunhong, Basic Issue Studies on Literary Anthropology in China, Kunming: Yunnan University Press, 2012 , p. 207.

${ }^{5}$ Michel de Certeau, The Writing of History. Translated by Tom Conley, New York: Columbia University Press, 1998 , p. 21.
} 
becoming historical? Or history becoming mythological? Actually, the exploration like this has a slight significance because myths contact with history together all the time. Mythological narration contains deep historical connotation and "historical truth". If we divide mythistroy into history and myths artificially, we will plug the possible breakthrough relating to literary, history and philosophy again on the postmodernism background.

Ye Shuxian put forward the concept of "mythistroy" formally in 2009 and announced the butt joint of Chinese literary anthropology theory's construction successfully. From then on, literary anthropology researchers strive to "draw the outline of primitive ancestors' historical memory and cultural codes by studying images and things in the long time before languages appeared, which takes mythological thinking preceding linguistic thinking as clue" ${ }^{\prime 6}$. Advocating myths shouldn't be in a state of marginalization and fragmentation from beginning to end, meanwhile, it shouldn't be in the class of folk literature as an onlooker. It's time to break up the situation where myths are inequitably at the corner of literature! The publication of Mythistrorical Books not only examines the progress in interpreting Chinese cultural prototype codes in the mythistorical horizon, but accumulates the practical experience for specific operation level of mythistorical theory.

On the one hand, we have interpreted some Chinese ancient classical books from the perspective of mythistory preliminarily, such as Ceremonial Etiquette (儀禮), The Book of Sites (禮記), Spring and Autumn Annals (春秋), Huainan Tzu (淮南子), etc.. It doesn't preach and pursue cultural fundamentalism, but explores the venation and track of Chinese mythistory. On the other hand, the mythistory is adapted to the interpretation of other mythistory in the world, and therefore Korean Mythistory (2012) and Sumer Mythistory (2014) are the best examples. After absorbing the latest achievements of international mythology widely, literary anthropologists begin to focus on the latest states of mythological development and strive to make their voice from the perspective of mythistory.

The proposition and application of the theory of "mythistory" can eliminate the distinct opposition of history and myths in a large extent, break up the literature-centered limitation of mythological research successfully, liberate myths from the narrow concept of discipline, exert its integrated advantage of penetrating literary, history and philosophy, and exert the methodological function of cultural codes and sacred narration. The theoretical horizon of mythistory can unearth "Da Vinci Code" which can explore the origin of Chinese civilization in the field of Chinese traditional culture.

\section{Great Tradition/Little Tradition: The Breakthrough and Awareness of "People Becoming Muddled From Recognizing Characters"}

In 1956, Robert Redfield, an American anthropologist, proposed the binary analytical concept of "great tradition and little tradition" for the first time in Peasant Society and Culture: An Anthropological Approach to Civilization, aiming at indicating two kinds of different level but concurrent traditions in a complex society:

In a civilization there is a great tradition of the reflective few, and there is a little tradition of the largely unflective many. The great tradition is cultivated in schools or temples; the little tradition works itself out and keeps itself going in the lives of the unlettered in their village communities. The tradition of the philosopher, theologian, and literary man is a

\footnotetext{
$6 \mathrm{Yu}$ Yurong, From "Myths and History" to "Mythistory", Centered on the Change of Relationship between "Myths" and "History" in the 20th Century, Folklore Studies, 2014 (2).
} 
tradition consciously cultivated and handed down; that of the little people is for the most part taken for granted and not submitted to much scrutiny or considered refinement and improvement. ${ }^{7}$

Obviously, the great tradition proposed by Robert Redfield is a writing cultural system controlled by a minority of intellectuals, representing country and belonging to an "elite culture"; while the little tradition is a mass cultural system inherited an oral heritage by a majority of farmers, representing countryside and belonging to a "popular culture".

However, based on the consideration of academic ethic, Ye Shuxian and other domestic literary anthropologists indicate that, the classified method created by Robert Redfield contains the value orientation of elitism, so they transform the set of concepts and divide them into new forms from the opposite direction once again. They take the preliterate oral cultural tradition as "great tradition", while the writing cultural tradition coded by Chinese characters as "little tradition". This classified standard is historical time, not who controlling the power of writing of characters. Although Ye's concept and Redfield's concept have the same name, their meaning is different. The conceptual breakthrough means to link preliterate era and postliterate era together, and makes a new integration and systematical cognition about Chinese culture.

After defining the concept of the great tradition and little tradition, we need to discuss the relationship of them. From the bidirectional observational perspective, Ye Shuxian has given out his explanation as follows: "As to the little tradition, the great tradition breeds and generates it. The cultural gene and pattern created by the great tradition become a womb where the little tradition happens, and must have a great and deep effect on the little tradition. In another aspect, as to the great tradition, the little tradition can inherit and expand the influence of great tradition, even can replace and cover it to some extent." ${ }^{\prime 8}$ Thus it can be seen that the theory of great tradition hopes us to restore historical original appearance, and to reconstruct preliterate mythistory and postliterate folk cultural inheritance from the perspective of gene of Chinese great tradition- the mythological idea.

Recently, the theory of great tradition and little tradition increasingly causes attention and reflection in academical circles and is gradually applied to the discussion and interpretation about Chinese traditional culture. Scholars hope use the theory to promote some objects to a position and height where never reached in the past. $\mathrm{Hu}$ Jiansheng have made more profound research about the great tradition and put Confucius in historical context and social field of oral great tradition in order to discuss him once again. He thinks that:

Confucius is a scholar who actively learns, spreads and guards oral culture. The idea of oral knowledge of "more hearing" and the mythological authority of "less suspecting" indicate that Confucius believes the value of oral cultural great tradition. He is loyal to the mysterious power or holiness passed by oral culture, while he is suspicious of text writing tradition which is subsequent, emerging, derivative and inferior. ${ }^{9}$

Nowadays, Chinese literary anthropology is constructing a new theory on basis of cultural texts' great tradition and little tradition. Literary anthropologists still need to expand a deep interpretation and cognition about the little tradition with the help of new knowledge of great tradition. We believe that using the great tradition to reinterpret the little tradition will continually pass on in the future.

\footnotetext{
${ }^{7}$ Robert Redfield, Peasant Society and Culture: An Anthropological Approach to Civilization, Chicago: The University of Chicago Press, 1956, p. 70.

${ }^{8}$ Ye Shuxian, The Great Tradition and Little Tradition of Chinese Culture, Guangming Daily, 30 August 2012.

9 Hu Jiansheng, "More Hearing and Less Suspecting" of Confucius and Oral Culture, National Arts, 2014 (2).
} 


\section{Faith in Jade Myth: The Spread Driving Force of Chinese Civilization Core Values}

Ye Shuxian proposed the view of "faith in jade myth is the state religion of China" for the first time in a lecture held in Guizhou Minzu College (貴州民族學院) on November 30, 2008. Although he thinks that many things are "the defence and inheritance of the most profound state religion, namely the tradition of faith in jade myth", such as the wearing jade of tomb 23's owner in Lingjiatan culture (凌家灘文化), the jade dragon like bear in Hongshan culture (紅山文化) and the narration of “returning an intact jade Bi to Zhao" (完璧歸趙) in Records of the Grand Historian (史記), he still concentrates on the textual research of prototype relating to Chinese saint myths. Furthermore, he has got down to discussing the issue of faith in jade myth and further demonstrating the development of faith in jade myth as Chinese prehistoric state religion since 2000. From then on, he indicates that the faith in jade myth is the earliest faith phenomenon within the territory of China up to now, and actively proposes that we should take the "faith in jade myth" as "Chinese state religion" because it can show Chinese cultural gene and prototype codes.

Why the "faith in jade myth" can be called Chinese state religion?

Although the faith in jade myth hasn't settled churches, doctrines, canons, sacred books, and even rigorous religion organizations, it can show the most prominent and unique characteristics of local culture. As a religious phenomenon, Chinese jade worship has a long history and needs to access the horizon of Chinese religious history rapidly. Secondly, the faith in jade myth is the earliest faith phenomenon within the territory of China up to now whose god is heaven. The jade is the medium and letter from heaven, so original ancestors can choose the faith in jade myth to communicate with heaven and earth. Thirdly, as an original religion having regional characteristics in Northeast Asia, the faith in jade myth needs to satisfy the basic theoretical condition about the construction of religion. Emile Durkheim and Mircea Eliade emphasize that faith and rites are the component factors of religion. We can clearly comb the venation of forming an entirety of faith and rites from the evolution order of Xinglongwa culture (興隆洼文化) to Hongshan culture. ${ }^{10}$ Hence, taking the faith in jade myth as Chinese state religion, it can not only embody the religious faith trait of Chinese civilization and original ecology, but also correspond to the profound connotation of the core values of Chinese civilization.

With the publication of archaeological achievements about Shenmu (神木) Shimao sites (石峁遺址) in Shaanxi in December 2012, the discussion about "the jade road" (玉石之路) became more and more fierce. When a conference named "Chinese jade route and jade weapons seminar" was held in Yulin (榆林), many scholars got together, such as archaeologists, anthropologists, ethnologists, mythologists and folk collectors. Based on evidences provided by ancient Shimao city and Shimao jade, they carried out a fierce discussion around the theme of "transporting jade from the west to the east" and "the Yellow River section of the jade road". ${ }^{11}$ So through new discoveries of Shimao sites and jade wares, we have found a new spread intersection of two kinds of sports: spreading jade culture from the east to the west and transporting jade from the west to the east. And those discoveries have become frontier cases which investigate how the "faith in jade myth" unifies Chinese civilized process for the first time. In recent years, literary anthropologists have held nine investigative activities about “the jade and silk road” (玉帛之路) which vastly promote us to discuss and

\footnotetext{
${ }^{10}$ See Ye Shuxian's An Illustrated History of the Origin Chinese Civilization, Guangzhou: Nanfang Daily Press, 2014, pp. 69-74.

11 Tang Qicui, Review of the Research of "the Jade Route", Journal of Shanghai Jiaotong University (Philosophy and Social Sciences), 2013 (6).
} 
rethink the relationship between the great tradition called "the jade road" and the little tradition called "the silk road" once again.

The theory of "faith in jade myth" can't leave mythological research, so it is a theoretical innovation of new century's original exploration and it means to try to construct a new mode of original exploration which highly embodies natural characteristics of Chinese civilization, examining the idea of jade god of great tradition in Chinese civilization again. The dynamic model provided by the faith in jade myth has agent of jade mine which causes the occurring of civilization. But most importantly, the spiritual religious idea hided in social configuration, namely the "faith in jade myth is an important power behind the occurring of civilization for Chinese civilization", so we can say that the faith in jade myth directly drives the spread of Chinese civilization and brings Chinese mainstream core values to Chinese civilization.

\section{N-level Coding Theory: Coding and Decoding Conscientiousness of Chinese Culture}

At present, the whole literary anthropological circles start to think about the theoretical proposition of the great tradition and little tradition deeply. Literary anthropologists think that it is able to arrange N-level symbolic coding orders from the great tradition to the little tradition according to the chronological arrangement. And then, based on redistributing the relationship of great tradition to little tradition, we make cultural texts since ten thousand and contemporary writers' literary texts promote a new theoretical height, and construct a set of cultural symbolic coding theories "N-level coding theory" balancing diachronism and synchronicity. It should be a summary of the latest theory which restores and explores the start point of things-images' narration. At the same time, it not only indicates $\mathrm{N}$ kinds of expressional models of cultural prototype, but also really gets through the great tradition and little tradition.

Ye Shuxian indicates: "we call preliterate relics and images 1-level coding whose basic principle is dominated by mythological thinking. Then, formation of Chinese characters is called 2-level coding or secondary-level coding... And 3-level coding refers to ancient books written by Chinese characters previously... There is no doubt that contemporary writers' works which are on the top of historical program codes, so we call them N-level coding uniformly." 12 Obviously, N-level coding theory embodies the empirical research thought from things and images' narration to writing narration and manifests logical problems of material which "quadruple-evidence approach" ignored in a way. From the perspective of chronology, "N-level coding theory" has "extracted" oral and physical narration, according to the process of historical development and inherited degree.

In the world, from the popularity of Harry Potter written by Joanne Kathleen Rowling to the acceptation of Frogs created by Mo Yan (莫言), “mythological coding type” of Chinese and foreign writers has put forward new constructional commands in theoretical circles right now. The occurring of N-level coding theory will promote directly the reformation of traditional cultural perceptions. In addition, in the previous three coding of "N-level coding theory", whoever masters the deep code of procedural bottom and remediate the knowledge of great tradition well, then he/she will get works' deep connotation and tensile space easily.

\footnotetext{
12 Ye Shuxian, Zhang Mili, \& Liu Qianyue, Cultural Semiotics New Horizons of Great/Little Tradition, Xi'an: Shaanxi Normal University Press, 2013, pp. 6-7.
} 
The original intention of N-level coding theory's construction is that hoping intellectuals can consciously get out of literal prison and pursue new freedom of thought and academic freedom under the influence of every level coding, especially young scholars. To our delight, more and more literary anthropologists have taken part in the study about the symbol coding process of cultural texts. Nowadays, there are more research papers about $\mathrm{N}$-level coding theory than before. Literary anthropologists are making an effort to construct a set of coding and decoding instructional theories.

For one thing, "N-level coding theory" absorbs Northrop Frye's theory of mythological "permutation and deformation"; for another thing, it learns from the methodology which makes James George Frazer's structuralism and typology together, Fernand Braudel's long periodic theory and the typological theory in archaeology. In addition, N-level coding theory and postmodern "intertextuality" created by Roland Barthes and Jacques Derrida have many similarities in connotation and commonly pay close attention to the problem of cultural formulation.

N-level coding theory constructed by literary anthropologists study the process that human how to "memorize" cultural prototype, and explain the result of "long periodic memory" embodying the ability of promoting human civilized progress, in order to advocate Chinese cultural coding and decoding conscientiousness. Nowadays, we only have an insight into cultural codes of primitive mythological thinking in the great tradition, so literal recoding of little tradition will make its goal of seeking roots become true.

\section{“Protestantism Revolution of Faith in Jade Myth”: Unifying China From Material and Spirit Again}

Chinese literary anthropologists put forward a theory of "Protestantism revolution of faith in jade myth", and indicated that the faith in jade myth unifies China for the first time, while the white jade worship realizes the unification of China from material and spirit once again. So it's a further unification and innovation about research achievement of the faith in jade myth theory.

When modern anthropologists conducted their religious studies, they only paid attention to the influence of sacred things to human social life, but ignored the inherent significance of symbolic signs. So Clifford Geertz gives an incisive criticism on the phenomenon like this:

The anthropological study of religion is therefore a two-stage operation: first, an analysis of the system of meanings embodied in the symbols which make up the religion proper, and, second, the relating of these systems to social-structural and psychological processes. My dissatisfaction with so much of contemporary social anthropological work in religion is not that it concerns itself with the second stage, but that it neglects the first, and in so doing takes for granted what most needs to be elucidated. ${ }^{13}$

By comparison, we find that people just ignore the significance of sacred symbolic signs, but pay more attention to jade wares' influence on the identity and position to themselves in the ritual process than before. So the faith in jade myth has been ignored by researchers intentionally or unintentionally, let alone the white jade of Protestantism. "Protestantism revolution of faith in jade myth" isn't constructed without any foundation. The records about "the white jade" are very common in the literal little tradition of the pre-Qin period, such as

${ }^{13}$ Cllifford Geertz, The Interpretation of Cultures: Selected Essays by Clifford Geertz, New York: Basic Books, 1973 , p. 125. 


\section{Mountains-Seas Book, Bamboo Annals (竹書紀年), The Songs of Chu (楚辭), The Book of Rites and so on.}

All records without being interrupted in above books don't indicate that there are a huge quantity of white jade. On the contrary, they just indicate the rareness and holiness of white jade and directly reflect people's cherish and worship for them. According to statistics, there are more than 142 mountains produced jade in Mountains-Seas Book, and especially 16 mountains produced "the white jade" at least. The proportion of latter exceeds 10\%. Obviously, the narrator of Mountains-Seas Book has already distinguished "the white jade" from "jade". But what factors can make him emphasize the "white" color specially? As we know, jade represents god in the pre-Qin period. Because the white jade is the most honorable symbol, the ancient people have a lofty faith in their heart. Thus the narrator's creative motivation driven by the white jade worship is undoubtedly.

When Max Weber demonstrated the Protestant ethic and the spirit of capitalism, he adopted both positive and negative ways. First, he sought a reason and result produced the spirit of capitalism in the interior of western civilization. Second, he got to other non-western society to do research, hoping to prove that the religious spirit of non-western world doesn't bring out the spirit of capitalism.

Different from Max Weber, we need to find out a reason and result of civilization, or an idea of jade god disappeared for a long time, not a reason and result of consciousness. From the phenomenon of "only jade buried with the dead" (唯玉為葬) in prehistoric upper-level tombs to the individual design of "gold inlaid with jade" (金鑲玉) at the Olympic games in 2008, the faith in jade myth has dominated China over thousands of years. As a special "internal language" in Chinese traditional culture, the sacred symbolic system hasn't been interrupted. The faith in jade myth isn't profane and is suitable for Chinese perfect ideal of "flawless white jade” (白璧無瑕), so we need to attach importance to the opposite effect of the spirit to the material, cast the sacred idea on the white jade and recover the common core and mainline of Chinese prehistoric faith. At the same time, we also need to find out the driving force of internal faith to open a new window of Chinese civilization. Only in this way can we realize the goal unifying China from material and spirit again.

\section{Conclusion}

Chinese literary anthropology theory's construction aims at breaking through the restraint of western paradigm of knowledge, not bringing it from the west directly. Frankly speaking, the theory of Chinese literary anthropology has a responsibility to guide local cultural conscientiousness and construct a theoretical system of cultural research and interpretation with distinct Chinese characteristics, making the literary view narrowed, rigidified and obeyed by modern college institution become more substantial than before. So we can reconstruct the local cultural idea and authentic Chinese literary idea of literary anthropology, avoiding falling into a controversial vicious cycle of value judgment again.

However, the process of theoretical construction still face many unanswered new and old problems and challenges, such as the evidence interrelation of quadruple-evidence approach, the relationship of faith in jade myth and economy and the dynamic factor of "Protestantism revolution of faith in jade myth", etc. And therefore, we must acknowledge that under the background of seeking roots in global culture and the trend of literature turning to anthropology, the construction of Chinese literary anthropology theory still has a long way to go in the future! 


\section{References}

Dai, Y. H. (2012). Basic issue studies on literary anthropology in China. Kunming: Yunnan University Press. de Certeau, M. (1998). The writing of history. (Tom Conley, Trans.). New York: Columbia University Press. Geertz, C. (1973). The interpretation of cultures: Selected essays by Clifford Geertz. New York: Basic Books. Hu, J. S. (2014). "More hearing and less suspecting" of Confucius and oral culture. National Arts, 2.

Redfield, R. (1956). Peasant society and culture: An anthropological approach to civilization. Chicago: The University of Chicago Press.

Tang, Q. C. (2013). Review of the research of "the Jade Route". Journal of Shanghai Jiaotong University (Philosophy and Social Sciences), 6.

Ye, S. X. (1992). "World Insight" and "Chinese Learning": My research on literary anthropology. Literature and Art Contending, 5.

Ye, S. X. (2009). Chinese history of myths from "Chinese Myths" to "Mythological China". Journal of Bai Se College, 1.

Ye, S. X. (2012). The Golden Bough and the Jade Leaf comparative mythology from Chinese perspective. Shanghai: Fudan University Press.

Ye, S. X. (2012). The great tradition and little tradition of Chinese culture. Guangming Daily, 30 August 2012.

Ye, S. X. (2014). An illustrated history of the origin Chinese civilization. Guangzhou: Nanfang Daily Press.

Ye, S. X., Zhang, M. L., \& Liu, Q. Y. (2013). Cultural semiotics new horizons of great/little tradition. Xi'an: Shaanxi Normal University Press.

Yu, Y. R. (2014). From "Myths and History" to "Mythistory" centered on the change of relationship between "Myths" and "History" in the 20th century. Folklore Studies, 2. 